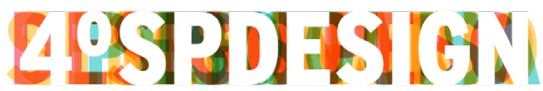 \\ Seminário de Pesquisa \\ Programa de Pós-Graduação \\ Design FAU USP
}

\section{Desenhando o invisível: paralelos entre o grid do design gráfico moderno e do digital contemporâneo}

\author{
Alice Viggiani, Clice de Toledo Sanjar Mazzilli
}

\author{
grid; design gráfico moderno; design digital
}

O design gráfico moderno antecipou aspectos do design digital online contemporâneo. Este trabalho pretende investigar que aspectos são estes e de que forma o momento atual resgatou pontos fundamentais da escola moderna, tais como visão programática, racionalização do processo criativo e linguagem objetiva. Com foco no que foi produzido no movimento moderno europeu das décadas de 1950 e 1960, a pesquisa estabelecerá paralelos que podem ser traçados em relação ao design digital desde os anos 2010 até os dias atuais. Considerando uma perspectiva formal, a pesquisa pretende investigar de que maneira a estrutura gráfica do desenho foi concebida e sistematizada conceitualmente nesses dois momentos. Que transformações ocorreram com o grid, desde quando foi elaborado por cânones modernos até sua construção atual, incremental e colaborativa? Dessa forma, o grid é o principal objeto a ser investigado, com o propósito de responder qual é

Curso

Mestrado

\section{Linha de Pesquisa}

Design: Processos e Linguagens

\section{Alice Viggiani \\ Designer gráfica formada em arquitetura pela FAU USP. É mestranda em design também pela FAU. Atua profissionalmente desde 2010, tendo já trabalhado no Masp, revista Bamboo e outros. e-mail: alice.viggiani@usp.br Lattes: http://lattes.cnpq. $\mathrm{br} / 2236597148420113$}

\section{Clice de Toledo Sanjar Mazzilli} Graduada em Arquitetura e Urbanismo pela FAU-USP (1984), onde realizou mestrado (1993), doutorado (2003) e livre-docência (2015) na área de Programação Visual.

e-mail: clice@usp.br

Lattes: http://lattes.cnpq. $\mathrm{br} / 9635315172253349$

Orcid: https://orcid.org/00000002-6903-9099 a influência do design gráfico moderno sobre a produção atual. Para tanto, as frentes de pesquisa são: 1. Levantamento e análise de manuais de design gráfico, compêndios, historiografias e documentos fundamentais que tenham sido escritos nos períodos mencionados, analisando quais trabalhos práticos fizeram uso de tais princípios formais postulados por esses documentos. Aqui, revisão bibliográfica e fontes da literatura tangenciam-se, na medida em que tais manuais serão tanto fonte de informação como objeto de estudo. 2. A partir desse levantamento, serão elencados e analisados visualmente trabalhos que demonstrem os parâmetros definidos por esses autores, tanto modernos quanto contemporâneos. A análise vai contar com um infográfico interativo. 3. Entrevistas com web designers. Porém, parte dos procedimentos propostos foram repensados por conta da pandemia. 


\section{Designing the invisible: Parallels between the modern graphic design grid and the contemporary digital design}

\author{
Alice Viggiani, Clice de Toledo Sanjar Mazzilli
}

Course

Master

Line of Research

Design: Processes and Languages

\begin{abstract}
Alice Viggiani
Graphic designer graduated in architecture from FAU USP. She is a master student in design at FAU. She works since 2010, having already worked at Masp, Bamboo magazine and others. e-mail: alice.viggiani@usp.br Lattes: http://lattes.cnpq. $\mathrm{br} / 2236597148420113$
\end{abstract}

Clice de Toledo Sanjar Mazzilli Graduated in Architecture and Urbanism at FAU-USP (1984), where she did her master's degree (1993), doctorate (2003), and livre-docência (2015) in the area of Visual Programming.

e-mail: clice@usp.br

Lattes: http://lattes.cnpq. $\mathrm{br} / 9635315172253349$

Orcid: https://orcid.org/00000002-6903-9099

\section{grid; modern graphic design; digital design}

Modern graphic design has anticipated aspects of contemporary online digital design. What are the most relevant aspects and how has the current reality restored fundamental points of the modern school - such as the programmatic vision, the rationalization of the creative process, and the goal oriented language - are the questions this work aims to investigate. With focus on what was produced in the modern European movement of the 1950s and 1960s, this research will be conducted considering the parallels that can be drawn from the comparison of digital design from 2010 until today. From a formal point of view, the research also aims to investigate how the graphic structure of design was conceived and systematized conceptually in these two moments. What changes have occurred with the grid since its elaboration by modern canons and how is it built today, incrementally and collaboratively? In this way, the grid is the main object to be investigated, aiming to answer what is the influence of modern graphic design and its current production. For this purpose the research objectives are: 1 . Survey and analysis of graphic design manuals, compendia, historiographies, and fundamental documents that have been written in the mentioned period, analyzing which practical works were made considering the use of the formal principles postulated by these documents. Here, bibliographic reviews and sources will be considered to be both sources of information and objects of study. 2. From this survey, we will list and visually analyzed works that demonstrate the parameters set by these authors, both modern and contemporary. The analysis will count with an interactive infographic. 3. interviews with web designers. However, some of these proposals are being revisited because of the pandemic. 